Uşak Üniversitesi Sosyal Bilimler Dergisi

$2015,8 / 4$

\title{
Sekizinci Sınıf Fen ve Teknoloji Dersine İlişkin Ortak Sınav Sorularının Değerlendirilmesi*
}

Asım ARI**

Tuğba İNCI ${ }^{* * * *}$

\section{Öz}

Araştırmada Sekizinci Sınıf Fen ve Teknoloji Dersine İlişkin Ortak Sınav Soruları'nın değerlendirilmesi amaçlanmıştır. Araştırma, nitel araştırma yaklaşımları kullanılarak yapılandırılmıştır. Araştırmanın veri kaynakları 2013-2014 yılında uygulanan Fen ve Teknoloji dersine ilişkin 40 $(20+20)$ Ortak Sınav sorusu ile bu sınava ilişkin $137(40+97)$ kazanımdan, çalışma grubu ise 18 Fen ve Teknoloji dersi öğretmeninden oluşmaktadır. Veriler öğretmen görüşme formu ve doküman incelemesiyle toplanmış, betimsel analizle çözümlenmiştir. Araştırma bulguları, Ortak Sınav sorularının sekizinci sınıf Fen ve Teknoloji Dersi Öğretim Programı'nda yer alan 137 kazanımdan 68'i ile ilgili olduğunu göstermiştir. Ortak Sınavlar'a ilişkin kazanımlar ve Ortak Sınav soruları alt düzey bilişsel basamaklarda yoğunlaşmaktadır. Yapılan görüşmelerde öğretmenler; Fen ve Teknoloji dersine ilişkin Ortak Sınavlar'da sorulan soru sayısını yeterli gördüklerini, soruların öğretim programıla uyumlu olduğunu fakat sınavda sadece programda yer alan bazı kazanımlara ağırlık verildiğini belirtmiştir. Ayrıca öğretmenler sınav sorularının daha seçici ve kapsamlı hale getirilmesini önermiştir. Bu araştırma Ortak Sınav sorularının Fen ve Teknoloji Dersi Öğretim programında yer alan kazanımların bir kısmına ilişkin olduğunu; sınav soruları ve sınava ilişkin kazanımların alt düzey bilişsel basamaklarda yer aldığını; Fen ve Teknoloji öğretmenlerinin, soru sayısını yeterli gördügünü fakat soruların seçicilik, kapsam gibi niteliklerinin artırılmasını vurguladığını göstermiştir.

Anahtar Kelimeler: Ortak Sinav, Ortak Sinav Soruları, Fen ve Teknoloji Dersi

\footnotetext{
* Bu makale Doç. Dr. Asım Arı'nın danışmanlığında yürütülen Tuğba İnci'nin "Sekizinci Sınıf Fen ve Teknoloji Dersine İlişkin Ortak Sınav Sorularının Değerlendirilmesi" adlı yüksek lisans tezinden (2014) yararlanılarak hazırlanmıştır.

${ }^{* *}$ Doç. Dr., Eskişehir Osmangazi Üniversitesi, Eğitim Bilimleri Bölümü

**** Arş. Gör., Eskişehir Osmangazi Üniversitesi Eğitim Fakültesi Eğitim Bilimleri Bölümü
} 


\title{
The Evaluation of Common Exam Questions regarding 8th Grade Science and Technology Lesson
}

\begin{abstract}
In this study, it is aimed to review the Common Exam Questions regarding Eight-Grade Science and Technology Lesson. The research was structured by using qualitative approaches. The data sources of the study consist of $40(20+20)$ Common Exam Questions regarding Science and Technology lesson implemented in 2013-2014 academic year and 137 (40+97) objectives concerning this exam while the study group is formed by 18 Science and Technology lesson teachers. The data of the study was collected by interview form and document review. The data got was analyzed by descriptive analysis. The findings of the study have showed that Common Exam Questions are related with 68 out of 137 objectives which take place in 8th grade Science and Technology Curriculum. The objectives as to Common Exams and Common Exam Questions have concentrated on low-level cognitive stages. The teachers have stated that the number of the questions asked in the Common Exams regarding Science and Technology lesson was adequate and the questions was compatible with the curriculum. However, they have pointed out that in the exams, it is concentrated only on some objectives in the curriculum. Moreover, the teachers have suggested that the exam questions should be more distinctive and comprehensive. This study has showed that Common Exam Questions were related with only some of the objectives in Science and Technology Curriculum and exam questions and objectives regarding the exam were at low-level cognitive stages. Moreover, the Science and Technology teachers find the number of the questions asked enough but they emphasize that the exams questions should be more distinctive and comprehensive.
\end{abstract}

Keywords: Common Exam, Common Exam Questions, Science and Technology Lesson.

\section{Giriş}

Günümüzde eğitimin niteliği ülkeler için gelişmişliğin ölçütü haline gelmiştir. Bilim ve teknolojideki ilerlemeler bilginin hızla artmasına, bu da eğitimden beklentilerin değişmesine sebep olmuştur. Eğitim programlarında gerçekleştirilen düzenlemelerle beklentiler karşılanmaya çalışılmaktadır (Arslan, 2000).

Eğitim programlarının istenilen başarıyı gösterip göstermediği ölçme değerlendirme ile belirlenir. Ölçme ve değerlendirmeyle eğitim- 
öğretim sürecinin sürekli izlenmesi ve ortaya çıkan sorunların tespit edilerek düzenlenmesi için fırsat sağlanır (MEB, 2005).

Ülkemizde, öğrencilerin eğitim gördükleri kademelerden sonra öğrenimlerine devam edecekleri bir üst kademedeki eğitim kurumlarını belirlemek amacıyla ölçme ve değerlendirmeden yararlanılmaktadır. Ortaöğretime geçiş sürecinde öğrencileri seçme ve yerleştirmeyle ilgili kararlar verilirken merkezi sınavlar yapılmaktadır. Önceki yıllarda LGS ve OKS adı altında yapılan bu sınavlar, 2008 yılından itibaren SBS adı altında yapılmaya başlanmıştır. 2013-2014 eğitim-öğretim yılı itibariyle öğrencilerin liseye geçiş sürecinde programdaki kazanımları elde etme seviyesini ölçen ve hangi liseye yerleşecekleri konusunda önemli bir faktör olan SBS kaldırılıp yerine Ortak Sınavlar uygulamaya konulmuştur.

Ortak Sınavlar; Türkçe, Matematik, Fen ve Teknoloji, Din Kültürü ve Ahlak Bilgisi, T.C. İnkılap Tarihi ve Atatürkçülük, Yabancı Dil olmak üzere altı derse yönelik sekizinci sınıfta öğretmen tarafından yapılan sınavlardan biri olarak yapılmaktadır. Ortak Sınavlar; güz ve bahar eğitim-öğretim dönemlerinde, iki yazılısı olan derslerden birincisi ve üç yazılısı olan derslerden ikincisi olarak gerçekleştirilmektedir. MEB'e (2013a) göre, öğrencinin bir sonraki eğitim kademesinde devam edeceği okulun belirlenmesinde ortaöğretime yerleştirmeye esas puan kullanılmaktadır. Yerleştirmeye esas puan; öğrencilerin 6,7 ve 8 'inci sınıf yılsonu başarı puanları ile 8'inci sınıf ağırlıklandırılmış Ortak Sınav puanları toplanıp elde edilen toplam ikiye bölünerek elde edilmektedir. Bu durum öğretmen, öğrenci ve veliler için Ortak Sınavlar'ın önemini artırmaktadır. Soruların; sınavların yapılacağı tarihe kadar işlenen öğretim programlarının belirlenen kazanımları esas alınarak ve öğrencinin eleştirel düşünme, analiz yapma, problem çözme, sonuç çıkarma, yorumlama gibi becerilerini ölçecek nitelikte hazırlanacağ 1 belirtilmektedir.

Bilişsel alanla ilgili taksonomiler; Bloom Taksonomisi (1956), Taba'nın Sinıflamasi, Gerlach ve Sullivan Taksonomisi, De Block Taksonomisi, Gagne-Merrill Taksonomisi, Solo Taksonomi (1982), Yenilenmiş Bloom Taksonomisi (2001), Fink Taksonomi (2003) ve Dettmer Taksonomi (2006)'dir (Arı, 2011; Kadayıfçı, 2007). Kazanımların sınıflandırılmasında çeşitli taksonomiler kullanılmıştır. Bu taksonomilerden biri de 1956 yılında Benjamin S. Bloom ve arkadaşları tarafından oluşturulan ve Bloom Taksonomisi olarak bilinen taksonominin 2001 yılında yenilenmiş hali olan Yenilenmiş Bloom Taksonomisi'dir. Bloom Taksonomisi sadece kazanımların sinıflandırılmasında değil, değerlendirme sürecinde sınav sorularının hazırlanmasında da kullanılabilmektedir (Bloom, 1956; Anderson ve diğerleri, 2001). Bloom Taksonomisi MEB'in program 
geliştirme ve ölçme-değerlendirme çalışmalarında dikkate aldığı taksonomidir.

Yenilenmiş Bloom Taksonomisi'ne göre farklı hücrelerde yer alan hedefler değerlendirilirken farklı yaklaşımlar gerektirir. Taksonomi tablosunda aynı hücrelerde yer alan hedeflerle ilgili değerlendirmeler ise benzer yaklaşımlar gerektirir. Bununla birlikte hedefler, öğretim ve değerlendirme arasında uyum olmalıdır. Örneğin; değerlendirmenin hedeflerle uyumlu olmadığı durumlarda değerlendirme sonuçları hedeflerle ilgili başarıyı yansıtamaz (Anderson ve diğerleri, 2010).

Ortak Sınavlar 2013-2014 eğitim-öğretim yılından itibaren uygulanmaya başlandığı için henüz bu sınavlara yönelik yapılmış herhangi bir çalışma bulunmamaktadır. Öğrencilerin eğitim yaşamlarını etkileyecek olan Ortak Sınav soruları ve bu sınava ilişkin kazanımların Yenilenmiş Bloom Taksonomisi'ne göre değerlendirilmesi, mevcut durumu açı̆̆a çıkaracaktır. Bu çalışma, bundan sonraki süreçte Ortak Sınavlar'ı hazırlayanlara Yenilenmiş Bloom Taksonomisi'ne göre hangi basamaklara ağırlık vermeleri konusunda ışık tutacaktır. Ortak Sınav sorularının öğretim programıyla tutarlılığının belirlenmesi, MEB'in sonraki sınavlarda daha nitelikli sorular hazırlayabilmesine yardımcı olabilecektir. Araştırmanın sonucuna göre öğretim programına konu eklenebilir veya konularda kısıtlamalar yapılabilir. Ayrıca araştırma kapsamında Ortak Sınavlarla ilgili öğretmen görüşlerinin alınması Ortak Sınavlar'ın öğretmenler açısından nasıl algılandığını ortaya çıkaracaktır.

Ortak Sınav sorularının; Fen ve Teknoloji Dersi Öğretim Programı ile Yenilenmiş Bloom Taksonomisi'ne uygunluk düzeyini belirleme ve Fen ve Teknoloji öğretmenlerinin Ortak Sınavlar'a ilişkin kişisel görüşlerini açığa çıkarma; kazanımlar, içerik, eğitim-öğretim süreci ve değerlendirmenin birbirleriyle uyum içinde olması açısından önemlidir. Böylelikle uygulanan sınavın amaca ne kadar hizmet ettiğinin belirleneceği düşünülmektedir.

MEB tarafından 2013 tarihli değişiklikle 1, 2, 3, 4. sınıflar ilkokul ve $5,6,7,8$. sınıflar ortaokul kategorisine ayrılmıştır. 8. sınıfların yılsonunda girdikleri SBS kaldırılmış yerine 2013-2014 Yılı Ortaöğretime Geçiş Sistemi getirilmiştir. Bu sistemle beraber 8. sinfflar güz ve bahar dönemlerinde olmak üzere yılda iki defa ortak sınavlara gireceklerdir. Ayrıca öğretim programlarında sadeleştirilmeye gidilmiş ve kazanım sayıları önemli ölçüde azaltılmıştır.

Fen ve Teknoloji Dersi Öğretim Programı'na ilişkin Ortak Sınav sorularının ve programda yer alan kazanımların YBT'ye göre hangi bilişsel basamakta ve bilgi boyutunda yer aldığın belirlemek; öğretmenlerin ve araştırmacıların işini kolaylaştıracaktır. Bu araştırma sonucunda; Fen Bilgisi 
öğretmenleri kendi sınavlarında soruları hazırlarken YBT'yi daha kolay kullanabilecektir çünkü kendi alanlarıyla ilgili örnekleri inceleme fırsatı bulacaktır. Araştırmacılar ise bu çalışmaya benzer ya da daha kapsamlı çalışmaları kendi alanlarında yapmak istedikleri takdirde bu çalışma onlar için kaynak teşkil edecektir.

Öğrencilerin eğitim yaşamlarını etkileyecek olan Ortak Sınav sorularının ve ders programındaki kazanımların YBT basamaklarına göre sınıflandırılması mevcut duruma farklı bir bakış açısı getirecektir. Araştırma sonuçları, bundan sonraki süreçte Ortak Sınav soruları hazırlanırken YBT'ye göre hangi öğrenme basamaklarına ağırlık verilmesi gerektiği konusunda soru hazırlayan görevlilere ışık tutacaktır. MEB sınav sorularını hazırlarken bu araştırma verilerinden faydalanabilecek; sorularla öğretim programının tutarlığı önemli olduğundan soruların ve kazanımların öğrenme basamaklarına dağılımının belirlenmesi yetkililere daha sonraki sınavların niteliğini artırmada yardımcı olabilecektir. Araştırma sonuçlarına göre programa konu eklenebilir veya sinav soruları kapsaminda ele alınan konularda kisitlamalar yapilabilir.

Araştırma sonucuna göre hem soruların programa uyumluluğu hem de soru ve kazanımların YBT'ye uyumluluğu artırılabilir. Ayrıca araştırma kapsamında Ortak Sınavlarla ilgili öğretmenlerin görüşlerinin alınması Ortak Sınavlar'ın öğretmenler açısından nasıl algılandığını ortaya çıaracaktır.

Bu araştırmada Sekizinci Sınıf Fen ve Teknoloji Dersine İlişkin Ortak Sınav Soruları'nın değerlendirilmesi amaçlanmıştır. Bu amaca ulaşmak için aşağıdaki sorulara yanıt aranmıştır:

1. Ortak Sınav sorularının Fen ve Teknoloji Dersi Öğretim Programı'na uygunluk düzeyi nedir?

2. Fen ve Teknoloji Dersi Öğretim Programı'na ilişkin Ortak Sınav sorularının YBT'ye uygunluk düzeyi nedir?

3. Ortak Sınavlar'a yönelik Fen ve Teknoloji dersi kazanımlarının YBT'ye uygunluk düzeyi nedir?

4. Fen ve Teknoloji dersi öğretmenlerinin Ortak Sınavlar'a ilişkin kişisel görüşleri nelerdir?

\section{Yöntem}

\section{Araştırma Deseni}

$\mathrm{Bu}$ çalışma nitel araştırma yaklaşımları kullanılarak yapılandırılmıştır. Araştırma iki boyuttan oluşmaktadır. İlk boyut, Ortak Sınav sorularının Sekizinci Sınıf Fen ve Teknoloji Dersi Öğretim Programı ile 
Yenilenmiş Bloom Taksonomisi'ne uygunluk düzeyini belirlemek; ikinci boyut, Fen ve Teknoloji Dersi öğretmenlerinin Ortak Sınavlar'a ilişkin kişisel görüşlerini derinlemesine incelemektir.

Fen ve Teknoloji Dersi öğretmenlerinin Ortak Sınavlar'a ilişkin kişisel görüşlerini derinlemesine inceleme boyutunda durum çalışması kullanılmıştır. Durum çalışması; güncel bir olguyu gerçek yaşam çerçevesi içinde çalışan, olgu ile içinde bulunduğu içerik arasındaki sınırların kesin hatlarıyla belirgin olmadığı ve birden fazla kanıt veya veri kaynağının mevcut olduğu durumlarda kullanılan araştırma yöntemidir (Yin, 1984 akt., Yıldırım ve Şimşek, 2011).

\section{Verilerin Kaynağı}

Araştırmanın ilk boyutunu oluşturan Ortak Sınav sorularının Sekizinci Sınıf Fen ve Teknoloji Dersi Öğretim Programı ile Yenilenmiş Bloom Taksonomisi'ne uygunluk düzeyini belirlemeye ilişkin veri kaynağını 2013-2014 eğitim-öğretim yılının güz ve bahar döneminde Sekizinci Sınıf Fen ve Teknoloji Dersine ilişkin sorulan $40(20+20)$ Ortak Sınav sorusu ve Ortak Sınavlar'a ilişkin Sekizinci Sınıf Fen ve Teknoloji Dersi Öğretim Programı'nda yer alan $137(40+97)$ kazanım oluşturmaktadır. Sekizinci Sınıf Fen ve Teknoloji Dersi Öğretim Programı́nda 197 kazanım yer almaktadır. Fakat bu çalışmada sadece Ortak Sınavlar'a ilişkin olan 137 kazanım değerlendirilmiştir.

\section{Çalışma Grubu}

Araştırmanın diğer boyutunu oluşturan Fen ve Teknoloji dersi öğretmenlerinin Ortak Sınavlar'a ilişkin kişisel görüşlerini derinlemesine incelemeye ilişkin çalışma grubunu; amaçlı örnekleme yöntemlerinden maksimum çeşitlilik örnekleme yöntemi kullanılarak seçilen ve Eskişehir ilindeki beş farklı ortaokulda çalışan 18 Fen ve Teknoloji dersi öğretmeni oluşturmaktadır. Olasılıklı ve seçkisiz olmayan bir örnekleme yaklaşımı olan amaçlı örnekleme; çalışmanın amacı doğrultusunda bilgi açısından zengin durumların seçilerek derinlemesine araştırma yapılmasıdır. Araştırmacı seçilen durumlar doğrultusunda doğa ve toplum olaylarını ya da olgularını anlamaya ve keşfedip açıklamaya çalışır (Büyüköztürk vd., 2010). Maksimum çeşitlilik örneklemesinde amaç; küçük bir örneklem oluşturmak ve oluşturulan bu örneklemde çalışılan probleme taraf olabilecek bireylerin çeşitliliğini büyük ölçüde yansıtmaktır (Yıldırım ve Şimşek, 2011). Okullar seçilirken öğrenci başarısı, bulundukları sosyoekonomik bölge ve sahip olunan imkanlar açısından farklı düzeylerde olmasına dikkat edilmiştir. Ayrıca çalışma grubunun çeşitliliğini sağlamada görüşleri alınan 
öğretmenlerin farklı cinsiyette olmaları, lisans mezuniyet bölümleri ve kıdemleri belirleyici bir unsur olarak kullanılmıştır.

Araştırmanın etiği çerçevesinde araştırmaya katılan öğretmenlerin isimlerini kullanmak yerine öğretmenler Ö1, Ö2, Ö3... Ö18 gibi kodlarla isimlendirilmiştir. Çalışma grubunda yer alan öğretmenler değişik demografik özelliklere sahiptir. Öğretmenlerin özellikleri aşağıdaki gibidir.

Tablo 1. Katılımcıların Demografik Özellikleri

\begin{tabular}{ccll}
\hline Katılımclar & $\begin{array}{l}\text { Mesleki } \\
\text { Deneyim }\end{array}$ & Lisans & Cinsiyet \\
\hline Ö1 & 6 & Eğitim Fakültesi & Erkek \\
Ö2 & 8 & Eğitim Fakültesi & Kadın \\
Ö3 & 9 & Eğitim Fakültesi & Kadın \\
Ö4 & 9 & Eğitim Fakültesi & Kadın \\
Ö5 & 10 & Eğitim Fakültesi & Erkek \\
Ö6 & 12 & Eğitim Fakültesi & Kadın \\
Ö7 & 12 & Eğitim Fakültesi & Kadın \\
Ö8 & 14 & Eğitim Fakültesi & Erkek \\
Ö9 & 15 & Eğitim Fakültesi & Kadın \\
Ö10 & 15 & Fen Edebiyat Fakültesi & Kadın \\
Ö11 & 17 & Fen Edebiyat Fakültesi & Kadın \\
Ö12 & 19 & Fen Edebiyat Fakültesi & Kadın \\
Ö13 & 20 & Fen Edebiyat Fakültesi & Kadın \\
Ö14 & 21 & Fen Edebiyat Fakültesi & Kadın \\
Ö15 & 30 & Fen Edebiyat Fakültesi & Erkek \\
Ö16 & 30 & Fen Edebiyat Fakültesi & Kadın \\
Ö17 & 32 & Fen Edebiyat Fakültesi & Erkek \\
Ö18 & 34 & Fen Edebiyat Fakültesi & Erkek \\
\hline
\end{tabular}

Tablo 4'te görüldüğü gibi araştırmaya katılan öğretmenlerin altısı erkek ve 12 'si kadındır. Araştırmaya katılan öğretmenlerin dokuzu eğitim fakültesi mezunu, altısı fen edebiyat fakültesi mezunu ve üçü eğitim enstitüsü mezunudur. Öğretmenlerin beşinin mesleki deneyimi 5-10 yıl, sekizinin mesleki deneyimi 11-20 yıl ve beşinin mesleki deneyimi 21-34 yıl arasındadır.

\section{Veri Toplama Araç ve Teknikleri}

Araştırmada Fen ve Teknoloji dersine ilişkin Ortak Sınav sorularının değerlendirilmesi amacıyla doküman incelemesi ve Fen ve Teknoloji 
öğretmenlerinin Ortak Sınavlara ilişkin görüşlerinin belirlenmesi amacıyla öğretmen görüşme formu kullanılmıştır.

\section{Doküman incelemesi}

Ortak Sınav sorularının Sekizinci Sınıf Fen ve Teknoloji Dersi Öğretim Programı ile Yenilenmiş Bloom Taksonomisi'ne uygunluk düzeyini belirlemek amacıyla veriler doküman incelemesi kullanılarak toplanmıştır. Yıldırım ve Şimşek (2011)'e göre doküman incelemesi, araştırılması amaçlanan olgu veya olgular hakkında bilgi içeren yazılı materyallerin analizini kapsar. Doküman incelemesi, nitel araştırmalarda tek başına bir araştırma yöntemi olabileceği gibi diğer veri toplama yöntemleri ile birlikte ek bilgi kaynağı olarak da kullanılabilir.

\section{Öğretmen görüşme formu}

Öğretmen görüşme formu, Fen ve Teknoloji dersi öğretmenlerinin Ortak Sınavlara ilişkin kişisel görüşlerini belirlemek amacıyla araştırmacı tarafından geliştirilmiştir ve toplam 15 açık uçlu sorudan oluşmaktadır. Açık uçlu sorular hazırlanırken cevabı evet ya da hayır olabilecek sorulardan kaçınılarak öğretmenlerin ayrıntılı bilgi verebilmelerini sağlayacak sorular tercih edilmiştir. Görüşme formunu hazırlamak için literatürden ve alan uzmanlarının görüşlerinden yararlanılmıştır. Görüşme soruları hazırlanırken literatür incelendikten sonra araştırmacının katkılarıyla yarı yapılandırılmış taslak bir görüşme formu oluşturulmuş ardından uzman görüşleri (Fen eğitimi, nitel araştırma ve eğitim programları ve öğretimi alanlarında uzman kişiler) alınmıştır. Uzmanlardan gelen öneriler doğrultusunda görüşme formunda değişiklikler yapılmıştır. Yarı yapılandırılmış görüşme formundaki soruların anlaşılabilirlik ve işlerliğini test etmek için iki Fen ve Teknoloji öğretmeniyle görüşme yapılmıştır. Bu görüşmelerin sonucunda görüşme formunda iki sorunun birleştirilmesine karar verilmiştir. Ayrıca görüşme formunda "Ortak Sınavlar " olarak yer alan ifadelerin öğretmenlere "TEOG Sınavı" şeklinde sorulmasına karar verilmiştir. Aksi takdirde bazı okullarda yazılı sınavlar ortak yapıldığı için öğretmenlerin yaptıkları ortak sınavlarla MEB'in yaptığı Ortak Sınavlar karıştırılabilmekte, yanlış anlaşılmalar olabilmektedir. Ayrıca genellikle öğretmenler Ortak Sınavları Temel Eğitimden Ortaöğretime Geçiş sisteminin kısaltması olan "TEOG" olarak adlandırmaktadır. Bununla birlikte ortaokul sekizinci sınıfta yapılan genel sinavların asıl adı "Ortak Sınavlar" olduğu için diğer bölümler bu doğrultuda hazırlanmıştır. Öğretmenlerle yapılan pilot görüşmeler sonucunda bir kısım soruların yeniden düzenlenmesi ile görüşme formunu oluşturan sorulara son hali verilmiştir. 
Sosyal Bilimler Dergisi 25

\section{Verilerin Toplanması}

Araştırmada veriler iki farklı aşamada elde edilmiştir. Birinci Aşama: Araştırmada Sekizinci Sınıf Fen ve Teknoloji Ders Programı'na MEB Talim ve Terbiye Kurulu'nun internet sitesi kullanılarak ulaşılmıştır. Sekizinci Sınıf Fen ve Teknoloji Dersi'ne ilişkin Ortak Sınav sorularına ise Milli Eğitim Bakanlığı Eğitim Teknolojileri Genel Müdürlüğü, Sınav Hizmetleri Daire Başkanlığı'nın internet sitesinden ulaşılmıştır. İkinci Aşama: Fen ve Teknoloji öğretmenlerinin Ortak Sınavlara ilişkin görüş ve deneyimlerinin değerlendirilmesine yönelik veriler yarı yapılandırılmış görüşme yöntemi kullanılarak elde edilmiştir. Veriler öğretmen görüşme formu yardımıyla çalışma grubundaki 18 öğretmenle araştırmacı tarafından bire bir gerçekleştirilen görüşmeler yoluyla elde edilmiştir. Görüşmeler katılımcların onayı alınarak ses kayıt cihazına kaydedilmiştir. Yarı yapılandırılmış görüşmeler esnasında araştırmanın amacı hakkında öğretmenlere bilgi verilmiş, öğretmenler tarafından anlaşılmayan soru olduğunda soruların anlaşılmasını sağlamak ve öğretmenlerin söylediklerine odaklanılarak gerekli yerlerde öğretmenlerin ifadelerinin daha anlaşılır olmasını sağlamak amacıyla sondaj soruları yöneltilmiştir.

Öğretmenlerle yapılan her bir görüşmede sorular aynı sırada sorulmamıştır. Görüşmenin ilerleyişi ve öğretmenlerden gelen cevaplar doğrultusunda soruların sırasında değişiklikler yapılmış, bazı sorular cevabı önceki sorularda verildiği için sorulmamıştır. Öğretmenlerle yapılan görüşmeler daha samimi cevaplar alabilmek amacıyla olabildiğince uzun tutulmuştur.

Öğretmenlerle yapılan görüşmelere öncelikle sosyo-ekonomik açıdan düşük düzeyli ve merkeze uzak okullarda başlanmıştır. İlk önce müdürlerle görüşülmüş ve izin belgesi gösterilmiştir. Okul müdürleri olumlu bir tavır sergilemiş ve araştırmacıyı öğretmenlere yönlendirmiştir. Araştırmacı öğretmenlerle ön görüşme yaparak boş ders saatlerini öğrenmiş ve görüşme yapmak amacıyla her bir öğretmen için ayrı ayrı görüşme zamanı ayarlamıştır. Bazı öğretmenlerle ise boş saatlerine denk geldiği için ön görüşmeye gidildiğinde görüşülmüştür.

Görüşmeler, 2013-2014 eğitim-öğretim yılı bahar döneminde mayıs ve haziran aylarında gerçekleştirilmiştir. Fen ve Teknoloji öğretmenleriyle görüşme yapılmasının bir avantajı olarak görüşme yapılacak yer konusunda sıkıntı yaşanmamış, görüşmeler genellikle okullarda fen laboratuvarlarında gerçekleştirilmiştir. Laboratuvarların uygun olmadığı durumlarda görüşmeler öğretmenler odasında, boş sınıflarda ya da çay odasında gerçekleştirilmiştir. 
Bazı durumlarda araştırmacı bazı durumlarda da öğretmenler görüşme zamanında okulda olamamıştır. Örneğin; araştırmaya katılan öğretmenlerden Ö4 "Soma Maden Faciası" için yapılan eylemlere katıldığı için görüşme gerçekleştirilememiştir. Bu öğretmenle dönem sonunda seminer zamanında görüşme yapılmıştır.

Araştırmacı öğretmenlerle görüşme yapmak ya da görüşme günü ayarlamak için bazı günler uzun süre öğretmenler odasında beklemek zorunda kalmıştır. Birkaçı dışında öğretmenler görüşmeleri son derece istekli olarak gerçekleştirmiştir. İlk başta anket dolduracaklarını sanıp olumsuz tepkiler veren ve yapmak istemediklerini belirten öğretmenler birebir görüşme yapılacağını öğrenince görüşmeyi kabul etmiştir. Öğretmenler görüşme esnasında ses kaydı yapılmasını normal karşılamıştır.

Araştırmacının Fen Bilgisi Öğretmenliği mezunu olması hem Fen ve Teknoloji dersi kazanımlarının sınıflandırılmasında hem de öğretmenlerle yapılan görüşmelerde kolaylık sağlamıştır.

\section{Verilerin Çözümlenmesi}

\section{Doküman analizi}

Ortak Sınav sorularının Sekizinci Sınıf Fen ve Teknoloji Dersi Öğretim Programı ile Yenilenmiş Bloom Taksonomisi'ne uygunluk düzeyinin belirlenmesi amacıyla öncelikle sınav sorularının programda yer alan hangi kazanımlara ilişkin oldukları araştırmacı tarafından belli periyotlarla belirlenmiş ve bir Fen Bilgisi öğretmeninin görüşüne sunulmuştur. Uyuşmayan noktalar tekrar gözden geçirilmiş ve Ortak Sınav sorularının programda yer alan hangi kazanımlara ilişkin oldukları tespit edilmiştir.

Ortak Sınav soruları ve bu sınava ilişkin kazanımların YBT'ye göre sınıflandırılmasında betimsel analiz kullanılmıştır. Betimsel analiz; elde edilen verilerin önceden belirlenen temalara, verilerden elde edilen temalara ya da görüşme-gözlem süreçlerinde kullanılan sorulara-boyutlara göre özetlenerek yorumlanmasıdır (Yıldırım ve Şimşek, 2011).

Araştırma kapsamında Sekizinci Sınıf Fen ve Teknoloji Dersi'ne ilişkin Ortak Sınav soruları ile Ortak sınavlar'a ilişkin kazanımlar YBT tablosu kullanılarak, araştırmacı tarafından YBT kitabında ve diğer çalışmalarda belirtilen açıklamalara göre bazı ölçütler belirlenerek belli periyotlarda sınıflandırılmıştır. Araştırmacı tarafından farklı zamanlarda yapılan sınıflandırmalarda örtüşmeyen soru ve kazanımlar tekrar gözden geçirilerek sınıflandırmaya son hali verilmiştir. Soru ve kazanımların sınıflandırılmış son hali Fen Eğitimi veya Eğitim Programları ve Öğretimi alanlarında ikişer uzman görüşüne sunulmuştur. İlk önce alan 
Sosyal Bilimler Dergisi 27

uzmanlarından birine kazanımlarla ilgili sınıflandırmanın son hali sunulmuş ve alınan geri bildirimler doğrultusunda örtüşmeyen maddelerle ilgili uzmanla görüşme gerçekleştirilmiş, bazı kriterler belirlenerek yeniden sınıflama yapılmıştır. Sınıflandırmanın bu son hali diğer uzmanın görüşüne sunulmuş ve aynı işlemler tekrarlanmıştır. Ortak Sınav soruları için de aynı işlemler gerçekleştirilmiştir. Elde edilen verilerin yüzde ve frekansları alınıp tablo ve grafikler haline getirilmiştir.

Veriler analiz edilirken Ortak Sınav soruları ve kazanımları YBT'ye göre birden fazla hücreye uygun olmaları nedeniyle bulgular kısmında verilen frekans tablolarında Ortak Sınav soruları/kazanımları toplamı ile çalışma grubunda yer alan kazanım/soru sayıları farklılık göstermektedir.

\section{Görüşme verilerinin çözümlenmesi}

Araştırmada toplanan yarı yapılandırılmış görüşme verileri analiz edilmeden önce görüşmelerden elde edilen verilerin deşifresi yapılmıştır. Her bir konuşma; araştırmacı tarafından hiçbir düzeltme yapılmadan, kelimesi kelimesine, görüşmeci-görüşen sırasıyla metne dönüştürülmüştür. Elde edilen verilerin analizinde Ortak Sınavların öğretmenler için ne anlama geldiği ile Fen ve Teknoloji öğretmenlerinin Ortak Sınavlara ilişkin görüş ve deneyimlerini açı̆̆a çıkarmak amacıyla betimsel analiz kullanılmıştır. Yıldırım ve Şimşek (2011)'e göre betimsel analizde doğrudan alıntılara sıkça yer verilir ve bulgular düzenlenip yorumlanarak okuyucuya sunulur.

Araştırmanın kavramsal boyutu, görüşme soruları ve görüşmede yer alan boyutlar kapsamında veri analizi için bir çerçeve oluşturulmuş ve verilerin hangi temalar altında sunulacağı belirlenmiştir. Oluşturulan bu çerçeveye göre elde edilen veriler düzenlenmiştir. Her bir katılımcının aynı soruya verdikleri cevapların bir arada görülebildiği bir şablon oluşturulmuştur. Bu şablonda ham veriler kodlama yapılarak kategorilere ayrılmıştır. Katılımcıların ifadelerinden elde edilen verilerde gerekli görülen kısımlara yeni kodlamalar eklenmiştir. Araştırmanın problemi ve amacına bağlı olarak gereksiz kodlamalar çıkarılmıştır. Kategorilerden alt temalar oluşturulup, bulgular bölümünde tema ve alt temalar altında verilerek okuyucu için anlamlı hale getirilmiştir. Daha sonra düzenlenen tema ve alt temalar tanımlanmış ve doğrudan alıntılara yer verilmiştir. Son olarak tanımlanan bulguların açıklanması, yorumlanması ve ilişkilendirilmesi gerçekleştirilmiştir.

Görüşme yapılan bazı öğretmenler, farklı alt temalara uygun birkaç görüş belirtmeleri nedeniyle bulgular bölümünde yer alan frekans tablolarında toplam öğretmen görüşleri sayısıyla çalışma grubundaki öğretmen sayısı farklılaşmaktadır. 


\section{Çalışmanın Geçerliği ve Güvenirliği}

Araştırmanın geçerliği ve güvenirliğini artırmak amacıyla şu işlemler gerçekleştirilmiştir:

- Araştırma kapsamında Ortak Sınav soruları ve bu sorulara ilişkin kazanımlar YBT'ye göre sinıflandırılmadan önce Lorin W. Anderson ve diğer eğitim uzmanları, ölçme değerlendirme uzmanları ve bilişsel psikologlarca hazırlanan 2001 yılında yayımlanmış "A Taxonomy for Learning, Teaching and Assessing- A Revision of Bloom's Taxonomy of Educational Objectives" adlı kitap ve çevirisine erişilerek taksonomi basamakları derinlemesine incelenmiştir. Ayrıca OBT ve YBT sınıflandırmaları ile ilgili yapılmış çalışmalar detaylı bir şekilde incelenerek taksonomi basamaklarının farklılıkları anlamlandırılmıştır.

- Ortak Sınavlar 2013-2014 eğitim-öğretim yılında uygulanmaya başlandığı için henüz bu sınavlara yönelik yapılmış bir çalışma bulunmamaktadır. Bu nedenle Fen ve Teknoloji dersine ilişkin OKS, SBS vb. genel sınav soruları ile ilgili yapılan araştırma sonuçlarına "Tartışma" bölümünde yer verilmiştir.

- Araştırmada kullanılan dokümanların analizi belli periyotlarda gerçekleştirilmiştir. Ayrıca öğretmenlerle yapılan görüşmelerin uzun tutulmasına dikkat edilmiştir.

- Araştırmada elde edilen veriler sürekli olarak birbirleriyle karşılaştırılıp yorumlanarak ve kavramsallaştırılarak örüntüler oluşturulmuştur.

- Araştırmada görüşmelerden elde edilen verilerdeki farklılıklar giderilerek ortak bir sonuca ulaşmak yerine veriler bütün zenginliğiyle verilmeye çalışılmıştır. Farklı verilerin elde edilebilmesi amacıyla da maksimum örnekleme yöntemi kullanılmış ve farklı özelliklerdeki öğretmenlerle görüşme yapılmıştır. Ayrıca Ortak Sınav sorularının ne düzeyde program konularıyla ilişkili olduğu araştırmacı tarafından belirlenmiş ve bu konuda uzman (Fen Bilgisi öğretmeni) görüşü alınmıştır. Ayrıca öğretmenlerle yapılan yarı yapılandırılmış görüşmelerde öğretmenlere bu konuda da sorular sorulmuştur.

- Araştırmacı çalışma sürecini ve sonuçlarını bir uzmana aktarmış, kendi yaklaşımı ve düşünce biçimini uzmanla beraber değerlendirmiştir. Uzmandan alınan geri bildirimler doğrultusunda düzenlemeler yapılmıştır.

- Araştırmada "Yöntem" bölümünde verilerin toplanması ve analiz edilmesiyle ilgili ayrıntılı bilgi verilmiştir. "Bulgular" bölümünde sık sık öğretmenlerle yapılan yarı yapılandırılmış görüşmelere ilişkin doğrudan alıntılara yer verilmiştir. 
- Araştırmada amaçlı örnekleme yöntemi kullanılarak hem genele hem de özele ait bilgiler açı̆̆a çıkarılmaya çalışılmıştır.

Araştırmanın tutarlılığıyla ilgili olarak veri toplama araçlarının oluşturulması, verilerin toplanması ve verilerin analizi aşamalarının birbiriyle tutarlı olmasına dikkat edilmiştir. Ayrıca görüşme esnasında öğretmenlere benzer yaklaşımla soru sorulmasına özen gösterilmiş ve görüşmeler kayıt altına alınmıştır. Araştırmada elde edilen verilerin kodlanması esnasında tutarlılığına dikkat edilmiş ve verilerin sonuçlarla ilişkileri incelenmiştir.

Araştırmada yapılan yorumların ham verilerle uyuşup uyuşmadığ 1 konusunda uzman görüşü alınmıştır.

\section{Bulgular ve Yorum}

\section{Ortak Sınav Sorularının Fen ve Teknoloji Dersi Öğretim Programına Uygunluğuna İlişkin Bulgular}

2013-2014 güz döneminde yapılan Ortak Sınavda Sekizinci Sınıf Fen ve Teknoloji Ders Programına ilişkin 20 soru bulunmaktadır. Bu soruların bir tanesi beş kazanıma, bir tanesi dört kazanıma, altı tanesi ikişer kazanıma ve 12 tanesi birer kazanıma ilişkindir.

2013-2014 bahar döneminde yapılan Ortak Sınavda da aynı şekilde Sekizinci Sınıf Fen ve Teknoloji Ders Programına ilişkin 20 soru bulunmaktadır. Bu soruların bir tanesi beş kazanıma, bir tanesi dört kazanıma, bir tanesi üç kazanıma, altı tanesi ikişer kazanıma ve 11 tanesi birer kazanıma ilişkindir.

Güz dönemi Ortak Sınavı toplamda programda yer alan 33 kazanıma ilişkin, bahar dönemi Ortak Sınavı ise 35 kazanıma ilişkindir. Güz ve bahar dönemi Ortak Sinavları hemen hemen aynı sayıda kazanımla ilişkilidir. 


\section{Ortak Sınav Sorularının Sinıflandırılmasıyla Elde Edilen Bulgular}

Tablo 4. Güz ve Bahar Dönemi Ortak Sınav Soruları ve Kazanımlarının Taksonomi Tablosundaki Dağılımı

\begin{tabular}{|c|c|c|c|c|}
\hline & Bilgi & Boyutu & & \\
\hline \multirow{3}{*}{$\begin{array}{l}\text { Bilişsel Süreç } \\
\text { Boyutu }\end{array}$} & Olgusal & Kavramsal & İşlemsel & Üstbilişsel \\
\hline & Ortak & Sinav & & \\
\hline & 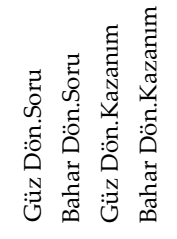 & 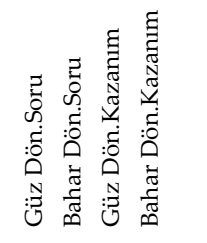 & 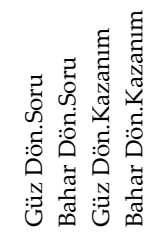 & 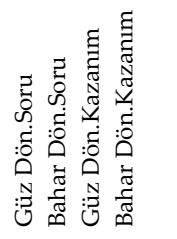 \\
\hline Hatırlamak & 3421 & $\begin{array}{llll}3 & 2 & 1 & 5\end{array}$ & & \\
\hline Anlamak & & 13142677 & 11314 & \\
\hline Uygulamak & & 1 & & \\
\hline Analiz etmek & & $4 \quad 41133$ & & \\
\hline Değerlendirmek & & & & \\
\hline Oluşturmak & & 24 & 1 & \\
\hline Toplam & 3421 & 202040120 & 113315 & \\
\hline
\end{tabular}

2013-2014 güz döneminde yapılan Ortak Sınav sorularının biri taksonomi tablosunda iki ayrı hücreye yerleştirilebildiği için bu sınavın ilişkili olduğu kazanım sayısı 20'den 21'e çıkmıştır.

Güz dönemi Ortak Sınavinda bilgi boyutunda, soruların neredeyse tamamının kavramsal bilgi türünde yer aldığı ve işlemsel bilgi türünde bir sorunun bulunduğu anlaşılmıştır. Olgusal bilgi ve üst bilişsel bilgi boyutunda herhangi bir soru yer almamaktadır. Bilişsel süreç boyutunda ise soruların anlamak, analiz etmek, hatırlamak ve uygulamak kategorilerinde yer aldığı görülmektedir. Bilişsel süreç boyutunda en çok soru anlamak kategorisinde yer almakta, değerlendirmek ve oluşturmak bilişsel süreç boyutlarında herhangi bir soru bulunmamaktadır.

Bütün bu bulgular ışı̆̆ında soruların en çok kavramsal bilgiyi anlamak kategorisinde yer aldığı söylenebilir. Soruların büyük bir bölümü (17 soru) alt düzey bilişsel basamaklarda, diğerleri (dört soru) üst düzey bilişsel basamaklarda yer almaktadır. 
2013-2014 bahar döneminde yapılan Ortak Sınav sorularının üçü taksonomi tablosunda ikişer hücreye yerleştirilebildiği için bu sınavın ilişkili olduğu kazanım sayısı 20'den 23'e çıkmıştır.

Bahar dönemi Ortak Sınavında bilgi boyutunda, soruların neredeyse tamamının kavramsal bilgi türünde yer aldığı ve olgusal bilgi türünde üç sorunun bulunduğu anlaşılmıştır. İşlemsel bilgi ve üst bilişsel bilgi boyutunda herhangi bir soru bulunmamaktadır. Bilişsel süreç boyutunda ise sorular hatırlamak, anlamak ve analiz etmek kategorilerinde yer almaktadır. Bilişsel süreç boyutunda en çok soru anlamak kategorisinde yer almakta, uygulamak, değerlendirmek ve oluşturmak bilişsel süreç kategorilerinde herhangi bir soru bulunmamaktadır.

Bütün bu bulgular 1şığında kazanımların en çok kavramsal bilgiyi anlamak kategorisinde yer aldığı söylenebilir. Soruların büyük bir bölümü (19 soru) alt düzey bilişsel basamaklarda, diğerleri (dört soru) üst düzey bilişsel basamaklarda yer almaktadır.

Güz dönemi Ortak Sınav soruları kavramsal bilgiyi analiz etmek kategorisinde yoğunlaşırken bahar dönemi Ortak Sınav soruları kavramsal bilgiyi anlamak kategorisinde yoğunlaşmaktadır.

\section{Edilen Bulgular}

Ortak Sınavlara İlişkin Kazanımların Sınıflandırılmasıyla Elde

2013-2014 güz döneminde yapılan Ortak Sınava ilişkin Sekizinci Sınıf Fen ve Teknoloji Ders Programında 40 kazanım bulunmaktadır. Bu kazanımlardan yedisi ikişer kazanım ifade ettiği için bu sayı 47’ye çıkmıştır. Bilgi boyutunda kazanımların kavramsal, olgusal ve işlemsel bilgi türünde yer aldığı görülmektedir. Kazanımların en çok kavramsal bilgi türünde yer aldığı anlaşılmıştır. Bilişsel süreç boyutunda kazanımların en çok anlamak boyutunda yer aldığı görülmektedir. Değerlendirme bilişsel süreç kategorisinde herhangi bir kazanım bulunmamaktadır.

Bütün bu bulgular ışığında kazanımların en çok kavramsal bilgiyi anlamak kategorisinde yer aldığı söylenebilir. Kazanımların büyük bir bölümü (34 kazanım) alt düzey bilişsel basamaklarda, diğerleri (13 kazanım) üst düzey bilişsel basamaklarda yer almaktadır. Kazanımların olgusal, kavramsal ve işlemsel olmak üzere üç bilgi türünde yer aldı̆̆ı, üst bilişsel bilgi türünde herhangi bir kazanımın bulunmadığı anlaşılmaktadır.

2013-2014 bahar eğitim-öğretim döneminde yapılan Ortak Sınava ilişkin Sekizinci Sınıf Fen ve Teknoloji Ders Programında 137 kazanım bulunmaktadır. Bu kazanımlardan 19 tanesi ikişer kazanım, bir tanesi üç kazanım ifade ettiği ve bir tanesi de duyuşsal alanla ilgili olduğu için bu sayı 156 'ya çımıştır. 
Bilgi boyutunda kazanımların olgusal, kavramsal ve işlemsel bilgi türünde yer aldığı, üst bilişsel bilgi türünde ise herhangi bir kazanımın olmadığı görülmektedir. Kazanımlar en çok kavramsal bilgi türünde yer almaktadır. Bilişsel süreç boyutunda kazanımların anlamak, analiz etmek, hatırlamak, uygulamak ve oluşturmak kategorilerinde yer aldığ 1 görülmektedir. Kazanımların en fazla anlamak boyutunda yer aldığı görülmüştür.

Bütün bu bulgular ışığında kazanımların en çok kavramsal bilgiyi anlamak kategorisinde yer aldığı söylenebilir. Kazanımların büyük bir bölümü alt düzey bilişsel basamaklarda (118 kazanım), diğerleri üst düzey bilişsel basamaklarda (38 kazanım) yer almaktadır. Üst bilişsel bilgi türünde herhangi bir kazanımın bulunmadığı anlaşılmaktadır. Bilişsel süreç boyutlarından değerlendirme kategorisinde herhangi bir kazanım yer almamaktadir.

Güz dönemi Ortak Sınav'ına ilişkin kazanımlar kavramsal bilgiyi analiz etmek basamağında yoğunlaşırken bahar dönemi Ortak Sınav'ına ilişkin kazanımlar kavramsal bilgiyi anlamak kategorisinde yoğunlaşmaktadır.

Güz dönemi Ortak Sınav soruları ve kazanımları kavramsal bilgiyi analiz etmek kategorisinde, bahar dönemi Ortak Sınav soruları ve kazanımları ise kavramsal bilgiyi anlamak kategorisinde yoğunlaşmaktadır.

\section{Edilen Bulgular}

Fen ve Teknoloji Öğretmenleriyle Yapılan Görüşmelerden Elde

\section{Ortak Sınavlara ilişkin görüşler}

Öğretmenlere Ortak Sınavlarla ilgili görüşleri sorulduğunda kimileri sınavın olumlu yönlerine dikkat çekerken, diğerleri olumsuz yönlerine vurgu yapmaktadır. 


\section{Ortak Sinavlara ilişkin olumlu görüşler}

Tablo 3. Ortak Sınavlara İlişkin Olumlu Görüşler

\begin{tabular}{ll}
\hline Alt Temalar & $\mathrm{f}$ \\
\hline Öğrencilerin streslerinin azalması & 11 \\
S̈navda ara verilmesi & 6 \\
Öğrenci-öğretmenin devamsızlık yapmamaya özen göstermesi & 5 \\
Değerlendirmenin sürece yayılması & 4 \\
Ders notları ve öğretmenin etkin hale gelmesi & 4 \\
Kazanımların ağırlıkta olması & 4 \\
Öğrencilerin motivasyonunun artması & 3 \\
Velinin maddi yönden rahatlaması & 1 \\
\hline Toplam & 38 \\
\hline
\end{tabular}

Tablo 3'de görüldüğü gibi araştırmaya katılan öğretmenlerin $11^{\prime}$ i Ortak Sınavların yapılmasıyla öğrencilerin stres düzeyinde azalma olduğunu belirtmiştir.

Öğretmenlerin Ortak Sinavlara ilişkin olumlu görüşleri doğrultusunda ortaya çıkan alt temalardan biri öğrencilerin stres düzeyinde azalmalar yaşandığına ilişkin görüştür. Öğretmenlere göre öğrencilerin sınav streslerinin azaltılmasında temel etken sınavın bölünerek iki dönemde yapılmasıdır.

Öğrencilerin sınavda yaşayacakları stresi parçaladılar, azaltarak ikiye böldüler (Ö18).

TEOG sınavının iki döneme yayılmış olması öğrenciler için büyük bir rahatlik (Ö13).

\section{Ortak Sınavlara ilişkin olumsuz görüşler}

Tablo 4. Ortak Sınavlara İlişkin Olumsuz Görüşler

\begin{tabular}{ll}
\hline Alt Temalar & $\mathrm{f}$ \\
\hline Sınav sonrası derslerin önemsenmemesi & 17 \\
Zamanlama hatası & 17 \\
Yanlış sınav tarzı & 11 \\
Firsat eşitsizliği & 5 \\
Liselere yerleştirme problemi & 4 \\
Odaklanma problemi & 2 \\
Sınavın önemini yitirmesi & 2 \\
Devamsızlık & 1 \\
\hline Toplam & 59 \\
\hline
\end{tabular}


Tablo 12'ye göre Ortak Sınavlarla ilgili olumsuz görüş belirten öğretmenlerin 17 'si sınav sonrasında derslerin önemsenmediğini belirtmiştir.

Öğretmenlerin Ortak Sinavlara ilişkin olumsuz görüşleri doğrultusunda ortaya çıkan alt temalardan biri Ortak Sınavlar'dan sonra öğrencilerin okulu ve dersleri önemsemediğine ilişkin görüştür. Öğretmenlere göre öğrenciler Ortak Sınavlar'dan sonra dönemin bittiğini düşünmektedirler.

TEOG bitti, okul bitti gibi düşünüyor öğrencilerin çoğu (Ö15).

Sonrasında kendilerini çok biraktılar, nasıl olsa sınav bitti diye çok gevşediler (Ö12).

Kopmalar olabiliyor ikinci dönemki TEOG'tan sonra. Yani öğrenciler bakanlık sınavına giriyor sonra bırakıyorlar, her şey bitmiş gibi algılıyorlar (Ö5).

\section{Sınav sorularına ilişkin görüşler}

Öğretmenlere Ortak Sınavlar'da sorulan soru sayılarının yeterliliği, kazanımlara uygunluk düzeyleri, konu dağılımları ve nitelikleriyle ilgili görüşleri sorulmuştur. Ayrıca öğretmenlere Ortak Sınav sorularının başarıyeteneği ve üst düzey öğrenmeyi ölçme düzeyine yönelik görüşleri sorulmuştur.

Öğretmenlerin Ortak Sınav Sorularına ilişkin görüşlerine Soru Sayısı, Kazanımlara Uygunluk, Konu Dağılımı, Nitelik, Başarı-Yeteneği Ölçme Düzeyi ve Üst Düzey Öğrenme açılarından bakılmıştır. 


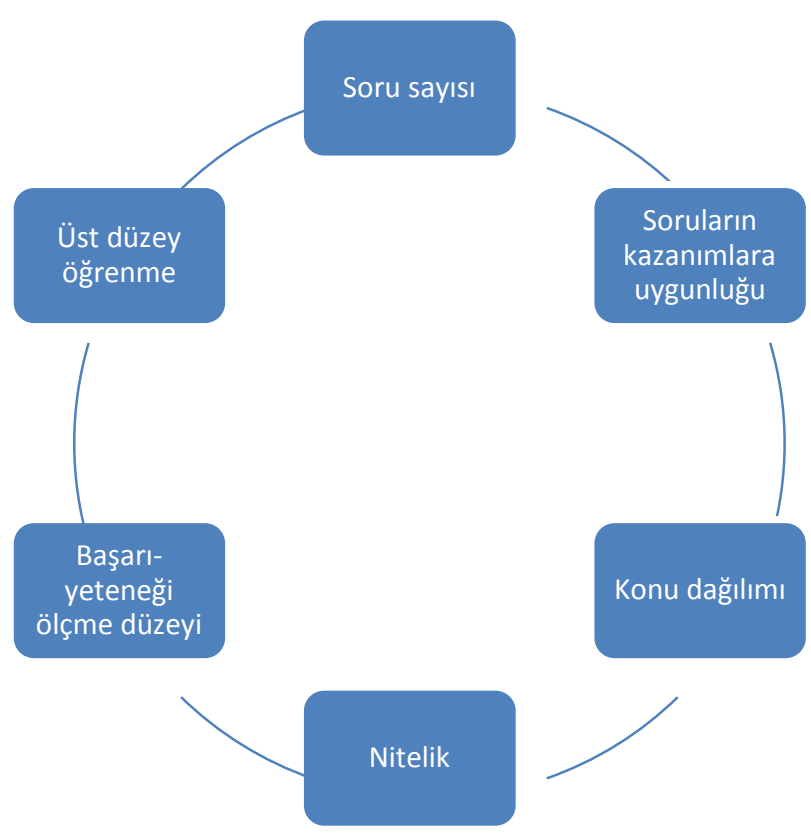

Şekil 1. Öğretmenlerin Ortak Sınav Sorularına İlişkin Görüşleri

\section{Soru sayısı}

Tablo 5. Soru Sayısına İlişkin Görüşler

\begin{tabular}{lc}
\hline Alt Temalar & $\mathrm{f}$ \\
\hline Yeterli & 9 \\
Yetersiz & 1 \\
\hline Toplam & 10 \\
\hline
\end{tabular}

Öğretmenlere Ortak Sınavlar'da sorulan Fen ve Teknoloji dersi sorularının ne düzeyde yeterli olduğuyla ilgili görüşleri sorulduğunda Tablo 5 'de görüldügü gibi dokuz öğretmen soru sayısının yeterli olduğunu ve bir öğretmen soru sayısının yetersiz olduğunu belirtmiştir.

Araştırmaya katılan öğretmenlerin yarısı Fen ve Teknoloji dersine ilişkin Ortak Sınav soru sayısını yeterli görmektedir.

Soru sayısı yeterli, 20 soru normaldir yani (Ö13).

Yeterliydi soru sayısı (Ö9).

20 soru olmasının yeterli olduğunu düşünüyorum (Ö2). 


\section{Soruların kazanımlara uygunluğu}

Tablo 6. Soruların Kazanımlara Uygunluğu İle İlgili Görüşler

\begin{tabular}{lr}
\hline Alt Temalar & $\mathrm{f}$ \\
\hline Kazanımlarla uyumlu & 24 \\
Tüm kazanımları kapsamamaktadır & 7 \\
Kolay kazanımlarla ilgili & 5 \\
Tüm kazanımlar değerlendirilemez & 5 \\
İlgili kazanımlara erişim düzey & 4 \\
\hline Toplam & 45 \\
\hline
\end{tabular}

Tablo 6'da görüldüğü gibi araştırmaya katılan öğretmenlerin 24'ü sınav sorularının kazanımlarla uyumlu olduğunu belirtmiştir.

Araştırmaya katılan öğretmenlerin tamamı Ortak Sınav Sorularının Sekizinci Sınıf Fen ve Teknoloji Ders programinda yer alan kazanımlarla örtüştüğünü belirtmiştir.

Sorular kazanımlarla örtüşmektedir (Ö3).

Sınavlar, ders kazanımlarıyla \%100 ölçüşüyor (Ö11).

Örtüştü̆̆̈̈nü düşünüyorum ben. Müfredata uygun, kazanımlara uygun, örtüşüyor. Müfredatın dışında, hiç bu sorulmamalıydı dediğgim soru olmadı (Ö8).

\section{Konu dă̆ılımı}

Tablo 7. Konu Dă̆̆llımıyla İlgili Görüşler

\begin{tabular}{lc}
\hline Alt Temalar & $\mathrm{f}$ \\
\hline Son işlenen konular ağırlıklı olması & 7 \\
İkinci sınavın ilkine göre daha iyi olması & 6 \\
Zor konular ağırlıklı olması & 2 \\
\hline Toplam & 15 \\
\hline
\end{tabular}

Tablo 7'ye göre araştırmaya katılan öğretmenlerin yedisi sınav sorularının ağırlıklı olarak son işlenen konulardan çıktığını belirtmiştir.

Öğretmenlerin bir kısmına göre Ortak Sınav sorularının konu dağılımında son işlenen konulara ağırlık verilmektedir ve öğretmenler bunun doğru olduğunu düşünmektedir.

Ilk TEOG sınavında işlediğimiz dar bir alandan, yaklaşık 10 kazanımdan 11 tane soru geldi. Ikkinci sinav içinde aynı şey geçerli. Sinırımız belli bu sınırın dışından ya da en çok konu yükü hangi konudaysa ondan soru 
gelmedi. Sorular en son işlenen konulardan ağırlıkl olarak geldi. Hani olması gerekende bu çünkü bu sınav bizim ikinci yazılımız için yapılıyor (Ö1).

İlk sinavda ikinci ünitenin ortasına kadar işledik, çok az bir konu var orada, sinav tamamen o az konudan çıkmış oldu. Ama ikinci TEOG'ta ilk dönemden soru vardl, tüm konulardan çıtı sorular. Birinci ve ikinci ünitenin yarısına kadar dediğim kısımdan birinci TEOG'ta zaten sınava tabi tutulduklarn için oradan çok ağırlıklı bir soru gelmedi. İlk TEOG sonrasından ă̆ırlıklıydı sinav (Ö2).

\section{Soruların niteliği}

Tablo 8. Soruların Niteliğiyle İlgili Görüşler

\begin{tabular}{lc}
\hline Alt Temalar & $\mathrm{f}$ \\
\hline Kolay olması & 17 \\
Çelişkili olması & 11 \\
İkinci sınav sorularının ilkinden iyi olması & 10 \\
Seçiciliğinin az olması & 10 \\
Bilgiye dayalı olması & 4 \\
Yoruma dayalı olması & 4 \\
Deneyle ilgili sorular olması & 3 \\
\hline Toplam & 59 \\
\hline
\end{tabular}

Tablo 8 'de görüldüğü gibi araştırmaya katılan öğretmenlerin $17^{\prime}$ si soruların kolay olduğunu belirtmiştir.

Öğretmenlerin bir kısmı Ortak Sınav sorularının çok basit olduğunu belirtmiştir.

Bu sinavda çok basit sorular soruldu (Ö12).

Ben soruları görünce yok artık, bu kadar da basit sorulabilir mi? dedim. Yani bir konunun en basit neyini sorabilirim, bunu sormuşlar (Ö13).

\section{Başarı-yeteneği ölçme düzeyi}

Tablo 9. Başar1-Yeteneği Ölçme Düzeyiyle İlgili Görüşler

\begin{tabular}{lc}
\hline Alt Temalar & $\mathrm{f}$ \\
\hline Başarıyı ölçmesi & 7 \\
Yeteneği ölçmemesi & 5 \\
Başarıyı ve yeteneği ölçmemesi & 2 \\
\hline Toplam & 14 \\
\hline
\end{tabular}


Tablo 9'da görüldüğü gibi araştırmaya katılan öğretmenlerin yedisi Ortak Sınavların öğrencilerin başarısını ölçtüğünü belirtmiştir.

Öğretmenlerin kimilerine göre Ortak Sınavlar öğrencilerin başarısını ölçmektedir.

Öğrencilerin başarı düzeylerini ölçüyor (Ö2).

Öğrencinin o dersteki başarısını ölçüyor (Ö16).

Öğrencinin o dersteki başarısını, anlayıp anlamadığını gösteriyor (Ö14).

\section{Üst düzey öğrenme}

Tablo 10. Üst Düzey Öğrenmeyle İlgili Görüşler

\begin{tabular}{lr}
\hline Alt Temalar & $\mathrm{f}$ \\
\hline Uygun değil & 11 \\
Kismen Uygun & 2 \\
Uygun & 1 \\
\hline Toplam & 14 \\
\hline
\end{tabular}

Tablo 10'a göre araştırmaya katılan öğretmenlerin 11'i Ortak Sınavların üst düzey öğrenme için uygun olmadığını belirtmiştir.

Araştırmaya katılan öğretmenlerin yarısından fazlası Ortak Sınavların üst düzey öğrenme için uygun olmamasının temel nedenini Ortak Sınav sorularının kolay olması olarak görmektedir.

Hayır. Kesinlikle üst düzey öğrenme için uygun değil. Çünkü yüzeysel bilgiye dayalı sorulardı, yoruma dayalı değildi (Ö9).

Genel olarak yapulabilir, basit sorular. Fen bilgisi gerektirmeden, soruda verilen şekillere göre yapılabilecek sorular. Fen bilgisini bilmesi gereken sorularda vardı (Ö5).

\section{Gerçek başarıyı yansıtma düzeyi}

Tablo 11. Gerçek Başarıyı Yansıtma Düzeyiyle İlgili Görüşler

\begin{tabular}{lr}
\hline Alt Temalar & $\mathrm{f}$ \\
\hline Gerçek başarıyı yansıtması & 14 \\
Gerçek başarıyı yansıtmaması & 8 \\
Gerçek başarıyı kısmen yansıtması & 1 \\
\hline Toplam & 23 \\
\hline
\end{tabular}


Tablo 11'de görüldüğü gibi araştırmaya katılan öğretmenlerin 14'ü Ortak Sınavlar'ın gerçek başarıyı yansıttığını belirtmiştir.

Öğretmenlerin bir kısmı Ortak Sınav sonuçlarının gerçek başarıyı yansıttığını belirtmiştir.

Gerçek başarıyı yansıttı, normalde iyi olan okulların TEOG sonuçları iyi çıkı (Ö13).

Sinıfta bizim gözlemlediğimiz sonuçlarla uyuşuyor, başarılı öğrenciler yine ayn sonuçları alıyor, orta seviyedeki öğrenciler yine aynı orta seviyede kalıyor, başarısız dediklerimiz de yine düşük seviyede. Bizim gözlemlerimizle en azından benim gözlemlerimle örtüşüyor (Ö8).

Bizim yaptığımız birinci ve üçüncü yazılılarla TEOG sınavı aşă̆ı yukarı paralellik gösterdi (Ö15).

\section{Mazeret sınavı}

Tablo 12. Mazeret Sınavıyla İlgili Görüşler

\begin{tabular}{lr}
\hline Alt Temalar & $\mathrm{f}$ \\
\hline Mazeret sınavına girenlerin şanslı olması & 12 \\
Mazeret sınavının kötüye kullanılması & 7 \\
Mazeret sinavının faydalı olması & 4 \\
\hline Toplam & 23 \\
\hline
\end{tabular}

Tablo 12'de görüldüğü gibi araştırmaya katılan öğretmenlerin 12'si mazeret sınavına giren öğrencilerin daha şanslı olduğunu belirtmiştir.

Öğretmenlerin bir kısmı mazeret sinavina giren öğrencileri daha şanlı görmektedir. Bu öğretmenlere göre mazeret sınav soruları ile gerçek sınav soruları çok benzerdir ve bu benzerlik adaletsizlik yaratmaktadır.

Özellikle ilk sınavla ilgili mazeret sinavını çok üzücü buluyorum, çünkü fen bilgisi soruları asıl sinavin aynısı gibiydi. Bu kadar benzer soru çıması hiç adil değil. En büyük sıkıntı bire bir, neredeyse aynı soruların sorulmasından kaynaklandı (Ö12).

Mazeret sınavında asıl sınavda çıkan soruların aynısı çıkıyor. Sorular farklı oluyor ama konu olarak neyle ilgili olduğu belli oluyor (Ö11). 


\section{Ortak sınavlar ve kaynaştırma öğrencileri}

Tablo 13. Ortak Sınavlar ve Kaynaştırma Öğrencileriyle İlgili Görüşler

\begin{tabular}{lc}
\hline Alt Temalar & $\mathrm{f}$ \\
\hline Olumsuz & 10 \\
Olumlu & 1 \\
\hline Toplam & 11 \\
\hline
\end{tabular}

Tablo 13'de görüldüğ̈̈ gibi araştırmaya katılan öğretmenlerin 10'u kaynaştırma öğrencilerinin Ortak Sınavlara katılmalarıyla ilgili olumsuz görüş belirtmiştir.

Bazı öğretmenlere göre kaynaştırma öğrencilerinin sınava girmeleri sorun oluşturmaktadır.

Öğrenme güçlü̆̆̈̈ çeken öğrenciler için Ortak Sinav sıkıntılı (Ö10).

Bence en büyük sorun kaynaştırma öğrencileriyle ilgili... bu çocuklar okuyamıyor, bazıları yazamıyor (Ö17).

\section{Öğrencilerin tepki ve değerlendirmeleri}

Tablo 14. Öğrencilerin Tepki ve Değerlendirmeleriyle İlgili Görüşler

\begin{tabular}{lr}
\hline Alt Temalar & $\mathrm{f}$ \\
\hline Olumlu tepki & 8 \\
Olumsuz tepki & 7 \\
Tepkisiz olma & 3 \\
\hline Toplam & 18 \\
\hline
\end{tabular}

Tablo 14'de görüldüğü gibi araştırmaya katılan öğretmenlerin sekizi öğrencilerin olumlu tepki verdiklerini belirtmiştir.

Öğretmenlerin bir kısmı öğrencilerin Ortak Sınavlarla ilgili olumlu tepki ve değerlendirmelerde bulunduğunu belirtmiştir. Araştırmaya katılan öğretmenlerden Ö17, Ortak Sınav sorularının kolay olduğu için öğrencilerin Ortak Sınavlar'dan ders yazılılarına kıyasla daha yüksek puanlar alıp sevindiklerini vurgulamıştır.

Öğrenciler başarılı oldukları için seviniyorlar. Yani bazen gerçek notlarının üzerinde alıyorlar, mutlu oluyorlar (Ö17). 
Araştırmaya katılan öğretmenlerden Ö2, öğrencilerin Ortak Sınavlar'ın SBS'den daha kolay olduğunun farkında olduklarını ve bu durumdan memnun olduklarını belirtmiştir.

Aslında tepkileri genelde iyi çünkü onlarda farkındalar SBS'nin daha büyük bir şey olduğunu, daha rahatlar (Ö2).

\section{Geri planda kalan öğrenciler}

Tablo 15. Geri Planda Kalan Öğrencilerle İlgili Görüşler

\begin{tabular}{lc}
\hline Alt Temalar & $\mathrm{f}$ \\
\hline Başarısız olan & 5 \\
Beklentisi yüksek olanlar & 3 \\
Özel yeteneği olan & 2 \\
Çalışma prensibi olmayan & 1 \\
Derse odaklanamayan & 1 \\
Öğretmeninin sınav bilgisi olmayan & 1 \\
Ailevi sorunlar yaşayan & 1 \\
Firsat eşitliği yakalayamayan & 1 \\
\hline Toplam & 15 \\
\hline
\end{tabular}

Tablo 15'de görüldüğü gibi araştırmaya katılan öğretmenlerin beşi başarısız olan öğrencilerin geri planda kaldığını belirtmiştir.

Araştırmaya katılan öğretmenlerin bir kısmına göre geri planda kalan öğrenciler genellikle başarısız olan öğrencilerdir.

Başarılı olmayan, biraz geri kalmış öğrenciler için Ortak Sınav sıkıntılı (Ö10).

Başarısız olan öğrenciler geri planda kalıyor (Ö4).

\section{Ortak Sınavların yapılma nedenleri}

Tablo 16. Ortak Sınavların Yapılma Nedenleriyle İlgili Görüşler

\begin{tabular}{ll}
\hline Alt Temalar & $\mathrm{f}$ \\
\hline Öğretmen-okulları değerlendirme & 6 \\
Göstermelik yapma & 3 \\
Değerlendirmeyi sürece yayma & 3 \\
Stresi azaltma & 2 \\
Dershaneleri kaldırma & 1 \\
Günü kurtarma & 1 \\
\hline Toplam & 16 \\
\hline
\end{tabular}


Tablo 16'da görüldüğg̈ gibi araştırmaya katılan öğretmenlerin altısı Ortak Sınavların öğretmen-okulu değerlendirmek amacıyla yapıldığını belirtmiştir.

Öğretmenlerin bir kısmına göre Ortak Sınavların yapılmasındaki temel neden öğretmen ve okulları değerlendirmektir.

En güzeli sınav yapalım, öğretmenleri değerlendirelim, okulu değerlendirelim diye düşünüyorum. TEOG sonuçlarında sadece kendi okulumuzun sıralamasın bilecek, diğer okulları bilmeyecektik. Kendimizin kaçıncı sırada olduğunu ya da girdiğimiz sınıflarda kaçıncı sırada olduğumuzu biliyoruz. Müdür bey toplantı yaptı, 8'lere giren tüm branş öğretmenlerini çă̆ırdı. Elinde zaten analizler vardl, orda sıralamalarımız vardı. Hem okul hem sinı hem öğretmenlerin sıralamaları vardı (Ö11).

\section{Sinav güvenliği}

Tablo 17. Sınav Güvenliğiyle İlgili Görüşler

\begin{tabular}{ll}
\hline Alt Temalar & $\mathrm{f}$ \\
\hline Güvenli değil & 8 \\
Güvenli & 1 \\
\hline Toplam & 9 \\
\hline
\end{tabular}

Tablo 17'de görüldüğü gibi araştırmaya katılan öğretmenlerin sekizi sınavın güvenli bir şekilde uygulanamadığını belirtmiştir.

Araştırmaya katılan öğretmenlerin bazılarına göre Ortak Sınavlar'da öğrenciler kendi okullarında sınava girdikleri için kopya olayları yaşanmaktadır. Bu öğretmenlere göre Ortak Sınavlar'da öğrenciler karma olarak sınıflara yerleştirilseler bile kendi okullarında sınava girdikleri için birbirlerini tanımaktadır.

Öğrencilerin kendi okullarında sınava girmesi konusunda aklıma takılan sorular var. Karma yapılsa da iki sinıf karıştırllıyor, öğrenciler tabi ki birbirlerini tanyorlar... sonuçta herkes birbirini biliyor, güvenlik açısından çok uygun olduğunu düşünmüyorum (Ö7).

Sinav zamanı her sinıftaki titizlik çok önemli... çocukların kendi okullarında TEOG'a girmelerinin dezavantajı da oldu, bu çocukların hepsi birbirini tanıyorlar (Ö13). 


\section{Öğretmenlerin Önerileri}

Tablo 18. Öğretmenlerin Ortak Sınavlara İlişkin Önerileri

\begin{tabular}{lc}
\hline Alt Temalar & $\mathrm{f}$ \\
\hline Soruların nitelikleri artırılmalı & 14 \\
Diğer türde sorular sorulmalı & 10 \\
Diğer (soru katsayıları, iptal edilen sorular, ders kitapları, & 10 \\
$\quad$ okulların donanımı, sınav kapsamı...) & \\
Sınav dönem sonunda yapılmalı & 9 \\
Soru sayısı arttırılmalı & 8 \\
Sınavlar ortaokul sürecine yayılmalı & 6 \\
Sınav sürecinde ara olmamalı & 2 \\
Soruların hazırlanması & 2 \\
Liseye geçiş sistemi & 2 \\
\hline Toplam & 63 \\
\hline
\end{tabular}

Tablo $18^{\prime}$ de görüldüğü gibi araştırmaya katılan öğretmenlerin 14'ü Fen ve Teknoloji dersine ilişkin Ortak Sınav sorularının niteliklerinin arttırılması gerektiğini vurgulamıştır.

Araştırmaya katılan öğretmenlerin büyük bir bölümü Fen ve Teknoloji dersine ilişkin Ortak Sınav sorularının seçicilik, zorluk, üst düzey öğrenme ve bilgi-yorum-deneye ilişkin olma açlarından niteliklerinin arttırılması gerektiğini belirtmiştir.

Öğretmenlerin bazıları başarılı öğrencileri ayırt edebilmek için Ortak Sınavlar'da seçici soruların olması gerektiğini belirtmiştir.

Üst düzey öğrencileri seçebilmek, ayırt edebilmek için kazanımların birbirleriyle ilişkili bir şekilde sorulmasını isterim bundan sonraki stnavlarda. Her öğrenciye yönelik çeşitli zorluk seviyelerinde sorular olmalı (Ö1).

\section{Sonuç, Tartışma ve Öneriler}

\section{Sonuç}

$\mathrm{Bu}$ araştırmada elde edilen sonuçlar şu şekildedir.

- 2013-2014 yılında uygulanan güz dönemi Ortak Sınav sorularl; Sekizinci Sınıf Fen ve Teknoloji Dersi Öğretim Programı'nda yer alan, bu sınava ilişkin 40 kazanımdan 33'ü ile ilgilidir. Bahar dönemi soruları ise bu sınava ilişkin 127 kazanımdan 35'ine yöneliktir. Ortak Sınavların kapsam geçerliliğinin düşük olduğu söylenebilir. 
- 2013-2014 yılında uygulanan Fen ve Teknoloji dersine ilişkin Ortak Sınav soruları genellikle alt düzey bilişsel basamaklarda yer almakta, üst düzey bilişsel basamaklardan sadece analiz etmek kategorisinde bazı sorular bulunmaktadır. Ortak Sınav soruları, kavramsal bilgiyi anlamak kategorisinde yoğunlaşmaktadır.

- 2013-2014 yılında uygulanan Ortak Sınavlara ilişkin kazanımlar genellikle alt düzey bilişsel basamaklarda yer almaktadır. Bununla birlikte, üst düzey bilişsel basamaklardan analiz etmek ve oluşturmak kategorilerinde bazı kazanımlar yer almaktadır. Değerlendirmek kategorisinde ise soru bulunmamaktadır.

- Araştırmaya katılan Fen ve Teknoloji öğretmenleri Ortak Sınavlara ilişkin olumlu ve olumsuz görüş belirtmiştir. Olumlu görüş belirten öğretmenler; Ortak Sınavların her iki dönemde de yapılmasıyla değerlendirmenin sürece yayıldığını ve böylelikle öğrencilerin streslerinin azaldığını, sınavda ara verilmesinin öğrenciler için iyi bir durum olduğunu, ders notları ve öğretmenlerin etkin hale geldiğini, Ortak Sınavların derste işlenen konulara yönelik olmasıyla öğrenci ve öğretmenlerin devamsızlık yapmamaya özen gösterdiğini belirtmiştir. Ayrıca öğretmenler yeni sınav sistemiyle öğrencilerin motivasyonlarının arttığını ve velilerin maddi yönden rahatladığını vurgulamıştır.

Olumsuz görüş belirten öğretmenler; Ortak Sınavların yanlış zamanda yapıldığını, yanlış sınav tarzının benimsendiğini, öğrenciler arasında fırsat eşitsizliğinin olduğunu, sınavda ara verilmesinden dolayı odaklanma problemi yaşandığını ve yüksek puan alan çok öğrenci olduğu için sınav sonuçlarına göre öğrencilerin liselere yerleştirilmesinde sıkıntı yaşanabileceğini vurgulamiştır.

- Öğretmenler Fen ve Teknoloji dersine ilişkin Ortak Sınav sorularını; sayı olarak yeterli görmekle birlikte soruların sadece öğretim programında yer alan bazı kazanımlara ilişkin olduğunu belirtmiştir. Ayrıca öğretmenler sınav sorularının kolay ve seçiciliklerinin düşük olduğunu, öğrenciler kendi okullarında sınava girdikleri için sınavın güvenli bir şekilde gerçekleştirilemediğini, mazeret sınavının kötüye kullanıldığını ve kaynaştırma öğrencilerinin Ortak Sınavlara girmelerinin yanlış olduğunu ifade etmiştir. Öğretmenler Ortak Sınav sorularının seçicilik, soru tipi gibi niteliklerinin artırılmasını ve Ortak Sınavların dönem sonunda yapılmasını önermiştir. 
Sosyal Bilimler Dergisi 45

\section{Tartışma}

Araştırma sonucunda Ortak Sınav sorularının Sekizinci Sınıf Fen ve Teknoloji Ders Programı'nda yer alan kazanımların tümüne değil, bir kısmına yönelik olduğu görülmüştür. Ayrıca bazı Ortak Sınav sorularının programda yer alan birkaç kazanıma ilişkin olduğu görülmüştür. Bu nedenle Ortak Sınavların öğrencilerin Fen ve Teknoloji dersine yönelik kazanımları elde etme düzeyini belirlemesi mümkün değildir, sınavın kapsam geçerliliğinin düşük olduğu söylenebilir. Özel (2010) ve Tolan (2011) Fen ve Teknoloji dersine ilişkin SBS sorularını değerlendirdikleri çalışmalarda benzer şekilde sınav sorularının programda yer alan kazanımların bir kısmına ilişkin olduğunu, bazı soruların birden fazla kazanımı ölçmeye yönelik olduğunu, sınavın kapsam geçerliliğinin yeterli olmadığını ve sınavın öğrencilerin kazanımları elde etme seviyesini belirleyemediğini tespit etmiştir. Bu araştırma kapsamında Fen ve Teknoloji öğretmenleriyle yapılan görüşmelerde öğretmenler benzer şekilde Ortak Sınav sorularının programda yer alan bazı kazanımlara yönelik olduğunu ve Ortak Sınavlarla öğrencilerin kazanımları elde etme seviyelerini belirlemenin mümkün olmadığını belirtmiştir.

Ortak Sınav sorularının ünitelere ve güz-bahar dönemlerine göre kazanımları ölçme oranları incelendiğinde, soruların hazırlanmasında nasıl bir yol izlendiği anlaşılmamaktadır. Bu durumun ölçme-değerlendirme konusunda ciddi standartların geliştirilmemiş olmasından kaynaklandığ 1 düşünülmektedir. Bu sonuç Tolan (2011)'ın SBS sınavını değerlendirdiği ve soruların nasıl bir plan çerçevesinde hazırlandığının belli olmadığını tespit ettiği çalışmasının sonuçlarıyla örtüşmektedir.

Fen ve Teknoloji dersine ilişkin Ortak Sınav soruları ve bu sınava ilişkin kazanımlar YBT'ye göre değerlendirildiğinde soruların ve kazanımların çoğunluğunun alt düzey bilişsel basamaklarda yer aldığı ve en çok kavramsal bilgiyi anlamak kategorisinde bulunduğu belirlenmiştir. Ortak Sınav soruları, bilgi türü olarak en çok kavramsal bilgi türünde ve bilişsel süreç boyutu olarak en çok anlamak kategorisinde yoğunlaşmaktadır. Bu sonuçlar; Çakıcı ve Girgin (2012)'nin ünite sonu değerlendirme sorularını incelediği, Ermurat, Gümüş, Kurt ve Feyatörbay (2011)'ın Fen Bilgisi dersinde sorulan soruların Bloom Taksonomisi'ne göre analizini yaptığı, Keskin ve Aydın (2011)'ın SBS altıncı sınıf Fen ve Teknoloji testinde yer alan Biyoloji sorularını Yenilenmiş Bloom Taksonomisi'ne göre incelediği çalışma sonuçlarıyla örtüşmektedir. Ayrıca Eş (2005)'in LGS Fen Bilgisi soruları ile Fen Bilgisi dersi sınav sorularını, Özcan ve Oluk (2007)'un Fen Bilgisi dersi sınav sorularını, Tolan (2011)'ın Fen ve Teknoloji dersine 
ilişkin SBS sorularını, Mutlu, Uşak ve Aydoğdu (2003)'nun LGS Fen Bilgisi soruları ile Fen Bilgisi dersi sınav sorularını ve Çepni, Ayvacı ve Keleş (2001)'in Devlet Parasız Yatıll, Özel Okullar, Meslek Liseleri, LGS ile öğretmenlerin sordukları Fen Bilgisi sorularını inceledikleri çalışmalarda bu çalışmayla benzer şekilde soruların alt düzey bilişsel basamaklarda yoğunlaştığ1 görülmektedir. Zoller (1993), Zoller ve Tsaparlis (1997) 'in yaptıkları çalışmada da kimya öğretmenlerinin öğrencileri değerlendirmek için uyguladıkları sınavlarda çoğunlukla Bloom Taksonomisi'nde yer alan alt düzey bilişsel süreçlerle ilgili sorular sordukları anlaşılmıştır.

Araştırma sonucunda Ortak Sınav soruları ve kazanımlarının ağırlıklı olarak kavramsal bilgi türü ve anlamak bilişsel süreç kategorisinde yer aldığı bulunmuştur. Bu sonuç Arı ve Gökler (2012)'in sekizinci sınıf Fen ve Teknoloji dersine ilişkin SBS soruları ve programda yer alan kazanımları değerlendirdiği çalışmada elde ettiği sonuçlarla örtüşmektedir.

Arı ve Gökler (2012)'in sekizinci sınıf Fen ve Teknoloji dersine ilişkin kazanımların üst bilişsel bilgi dışında tüm kategorilerde yer aldığını belirtmiştir. $\mathrm{Bu}$ çalışmada ise kazanımların üst bilişsel bilgi ve değerlendirmek kategorisinde yer almayıp diğer tüm kategorilerde yer aldığı bulunmuştur. Bu farklılığın bu çalışmada sekizinci sınıf Fen ve Teknoloji dersi kazanımlarının tümünün değil Ortak Sınavlara ilişkin olan bölümünün değerlendirilmesinden kaynaklandığı düşünülmektedir. Ortak Sınavlara ilişkin kazanımlar sekizinci sınıf Fen ve Teknoloji programında yer alan son iki ünite kazanımlarını içermemektedir.

MEB, Ortak Sınav sorularının; sınavların yapılacağı tarihe kadar işlenen öğretim programlarının belirlenen kazanımları esas alınarak öğrencinin eleştirel düşünme, analiz yapma, problem çözme, sonuç çıkarma, yorumlama ve benzeri becerilerini ölçecek nitelikte hazırlanacağını belirtilmiştir (MEB, 2013a). Bu araştırmanın sonucunda, 2013-2014 eğitim öğretim yılı güz ve bahar dönemi Fen ve Teknoloji dersine ilişkin Ortak Sınav sorularının açıklandığı gibi üst düzey becerileri ölçecek nitelikte olmadığı belirlenmiştir. Fen ve Teknoloji dersine ilişkin Ortak Sınav soruları 2013 yılında uygulamaya konulan OGES (Ortaöğretime Geçiş sistemi)'e uygun değildir. Bu sonuç Tolan (2011)'ın MEB tarafından SBS sınav sorularının üst düzey öğrenmelerle ilgili olarak hazırlanacağının belirtildiğini fakat sınav sorularının üst düzey öğrenmelerle ilgili olmadığını tespit ettiği araştırma sonucuyla ilişkilendirilebilir.

Araştırmaya katılan öğretmenlere göre, Ortak Sınav soruları sekizinci sınıf Fen ve Teknoloji dersi konu ve kazanımlarına ilişkindir. Bu sonuç bu araştırmada soruların ilişkili oldukları kazanımlar değerlendirildiğinde elde edilen sonuçla örtüşmektedir. Çünkü bu 
araştırmada, Ortak Sınav sorularının programda yer alan tüm kazanımlarla ilişkili olmamakla beraber soruların programda yer alan kazanımlarla ilişkili olduğu sonucu elde edilmiştir. Öğretmenlere göre Ortak Sınavlar'da programda yer alan kazanımlara yönelik sorular sorulmakta ve bazı sorular birden fazla kazanımı değerlendirmektedir. Özel (2010) ve Tolan (2011), SBS Fen ve Teknoloji sorularını inceledikleri çalışmalarında benzer şekilde soruların programa uygun ve bazı sınav sorularının birden fazla kazanımı değerlendirmeye yönelik olduğunu bulmuştur.

Öğretmenler öğrencilerin yaşları, diğer derslerden de sınava girmeleri ve sınav süresi düşünüldügünde Fen ve Teknoloji dersine ilişkin Ortak Sınavlar'da çıkan soru sayısını yeterli görmektedir. Fakat öğretmenler nitelik, seçicilik, zorluk ve soru tipleri konusunda soru çeşitliliğinin artırılması gerektiğini belirtmiştir. Çakıcı ve Girgin (2012), ünite sonu değerlendirme sorularını öğretmen görüşlerine göre inceledikleri çalışmada benzer şekilde öğretmenlerin soru çeşitliliğinin arttırılması gerektiğini vurguladığını açığa çıkarmıştır. Bu doğrultuda MEB tarafından; Fatih projesi tüm bileşenleriyle uygulamaya geçildiğinde öğrencilere verilecek tablet bilgisayarların Ortak Sınavlar'da açık uçlu sorular sorulmasını sağlayacağ belirtilmiştir. Ayrıca açı uçlu soruların öğrencilerin bilişsel özellikleri dikkate alınarak hazırlanacağı, sınav değerlendirmesinin öğrencilerin kimlikleri gizli tutularak elektronik ortamda farklı öğretmenler tarafından yapılan değerlendirmelerin ortalamaları alınarak gerçekleştirileceği vurgulanmıştır (MEB, 2013b).

Araştırmaya katılan öğretmenlerin bir kısmı Ortak Sınav sorularının kendi hazırladıkları sorular ve kaynak kitaplarda yer alan sorularla zorluk, hesaplama ağırlıklı soruların olması ve soru tipleri açısından benzerlik göstermediğini vurgulamıştır. Ayrıca öğretmenler uygulamada yaşanan sıkıntılar nedeniyle öğrenme-öğretme etkinliklerini Ortak Sınavlar için yeterli görmemektedir. Bu sonuçların tümü, Özel (2010)'in Fen ve Teknoloji dersine ilişkin SBS sorularını değerlendirdiği çalışma sonuçlarını destekler niteliktedir.

Ortak Sınavlara ilişkin olumsuz görüş belirten öğretmenlerin bazıları sınavın niteliğinin arttırılması gerektiğini belirtirken yanlış cevapların doğruları götürmemesinin olumsuz bir durum olduğunu ve adaletsizlik oluşturduğunu belirtmiştir. Bununla ilişkili olarak MEB (2013b) Ortak Sınavların yazılı sınavlardan biri olarak yapıldığını ve öğrencilerin okullarda girdikleri diğer yazılı sınavlarda da yanlışların doğruları götürmediğini vurgulamıştır. Ayrıca YDS gibi yanlışların doğruları etkilemediği sınavlarda adayların rastgele doğru cevabı bularak başarılı olma ihtimallerinin dikkate alınmayacak kadar düşük olduğu vurgulanarak 
öğrencilerin rastgele bir yöntemle diğer öğrencilerin önüne geçmesinin ve bu durumun bir adaletsizlik teşkil etmesinin söz konusu olamayacağ 1 belirtilmiştir.

Okulda yapılan diğer sınavlar için geçerli olan mazeret şartları Ortak Sınavlar içinde geçerli olacaktır. MEB (2013b) mazeret sınavlarının; Ortak Sınavlarla eşdeğer nitelikte farklı sorularla ve öğrencilerin kendi okulları dışında farklı sınav salonlarında yapılacağı için öğrenciler tarafından tercih edilmeyeceğini belirtmiştir. Ayrıca öğrencilerin gerçekten mazeret sahibi olmadıkları durumlarda bu sinavlara girmek istemeyeceklerini vurgulamıştır. Fakat bu araştırma kapsamında Fen ve Teknoloji öğretmenleriyle yapılan görüşmeler sonucunda öğrencilerin mazeret sınavlarını kötüye kullandıkları, sahte rapor alarak mazeret sınavlarına girmeyi tercih ettikleri ve bazı dershanelerin ve velilerin öğrencileri mazeret sınavına girmeye yönlendirdikleri tespit edilmiştir.

\section{Öneriler}

- Fen ve Teknoloji dersine ilişkin Ortak Sınav soruları; birden fazla kazanıma ilişkin sorulursa, öğretim programında yer alan daha fazla kazanım değerlendirilerek sınavın kapsam geçerliliği artırılabilir.

- Ortak Sınavlar'da Fen ve Teknoloji dersine ilişkin üst bilişsel düzeyde sorular sorulabilir ve öğretim programlarında üst bilişsel düzeyde kazanımlara yer verilebilir.

- Ortak Sinavlar güz ve bahar dönemlerinin sonunda yapılarak öğrencilerin dönem sonuna kadar motivasyonları yüksek tutulabilir. Ortak Sınavlar'da daha fazla sayıda, çeşitli türlerde ve farklı zorluk seviyelerinde sorular sorularak sınavın seçiciliği artırılabilir.

\section{Kaynakça}

Anderson, L. W., Krathwohl, D. R., Airaisan, P. W., Cruikshank, K. A., Mayer, R. E., Pintrich, P. R., Raths, J., \& Wittrock, M. C. (2001). A taxonomy for learning, teaching and assessing: a revision of Bloom's Taxonomy of educational objectives. New York: Addison Wesley Longman, Inc.

Anderson, L. W., Krathwohl, D. R., Airaisan, P. W., Cruikshank, K. A., Mayer, R. E., Pintrich, P. R., Raths, J., \& Wittrock, M. C. (2010). Öğrenme öğretim ve değerlendirme ile ilgili bir sınıflama-Bloom'un eğitimin hedefleri ile ilgili sınıflamasının güncelleştirilmiş biçimi (D. A. Özçelik, Çev.). Ankara: Pegem Akademi. 
Arı, A. (2011). Bloom'un gözden geçirilmiş bilişsel alan taksonomisinin Türkiye'de ve uluslararası alanda kabul görme durumu. Kuram ve Uygulamada Eğitim Bilimleri, 11, 749-772.

Arı, A., \& Gökler, Z. S. (2012, Haziran). İlköğretim Fen ve Teknoloji dersi kazanımları ve SBS sorularının yeni Bloom Taksonomisi'ne göre değerlendirilmesi. 10. Ulusal fen bilimleri ve matematik eğitimi kongresi. Niğde Üniversitesi Eğitim Fakültesi, Niğde.

Arslan, M. (2000). Cumhuriyet dönemi ilköğretim programları ve belli başlı özellikleri. Milli Eğitim Dergisi, 146, 42-48

Bloom, B. S. (Ed.) (1956). Taxonomy of educational objectives. Handbook 1: The cognitive domain. New York: David McKay.

Büyüköztürk, Ş., Çakmak, E. K., Akgün Ö. E., Karadeniz, Ş., \& Demirel, F. (2010). Bilimsel araştırma yöntemleri. Ankara: Pegem.

Çakıcı, Y., \& Girgin, E. (2012). İlköğretim ikinci kademe Fen ve Teknoloji ders kitaplarındaki ünite sonu değerlendirme sorularının incelenmesi. Erzincan Üniversitesi Eğitim Fakültesi Dergisi, 14 (2), 87-110.

Çepni, S., Ayvacı, H. S., \& Keleş, E. (2001, Eylül). Okullarda ve lise giriş sinavlarında sorulan Fen Bilgisi sorularının Bloom Taksonomisi'ne göre karşılaştııılması. Yeni bin yılın başında fen bilimleri sempozyumu. Maltepe Üniversitesi Eğitim Fakültesi, İstanbul.

Ermurat, D. G., Gümüş, İ., Kurt, M. \& Feyatörbay, E. (2011) İlköğretim fen bilgisi dersinde sorulan sinav sorularının Bloom Taksonomisi'ne göre analizi (Erzurum örneği). Ekev Akademi Dergisi, 15 (49), 261269.

Eş, H. (2005). Liselere giriş sınavları fen bilgisi soruları ile ilköğretim fen bilgisi dersi sınav sorularının Bloom Taksonomisi'ne göre değerlendirilmesi (Yüksek Lisans Tezi). Gazi Üniversitesi, Ankara.

Kadayıfçı, K. G. (2007). Liselerde ve ÖSS sınavlarında sorulan kimya sorularının programa uygunluğunun incelenmesi (Yüksek Lisans Tezi). Gazi Üniversitesi, Ankara.

Keskin, M. Ö., \& Aydın, S. (2011). Seviye Belirleme Sınavı 6. sınıf fen ve teknoloji testinde çıkan biyoloji sorularının Revize Edilmiş Taksonomi'ye göre incelenmesi. Gazi Eğitim Fakültesi Dergisi, 31 (3), 727-742.

MEB (2013a). Millı̂ Eğitim Bakanlığı Ortaöğretim Kurumlarına Geçiş Yönergesi. http://oges.meb.gov.tr/

MEB (2013b). Sikça Sorulan Sorular. http://oges.meb.gov.tr/ssoru.htm

MEB (2005). Fen ve Teknoloji Dersi (6-8. Sınıflar) Öğretim Programı. 
Mutlu, M., Uşak, M., \& Aydoğdu, M. (2003). Fen bilgisi sınav sorularının Bloom Taksonomisi'ne göre değerlendirilmesi. Kırşehir Eğitim Fakültesi Dergisi, 4 (2), 87-95.

Özcan, S. \& Oluk, S. (2007). İlköğretim fen bilgisi derslerinde kullanılan soruların Piaget ve Bloom taksonomisine göre analizi. Ziya Gökalp Eğitim Fakültesi Dergisi, 8, 61-68.

Özel, R. (2010). Seviye Belirleme Sınavı sorularının Fen ve Teknoloji programları ile öğretmen ve öğrenci görüşleri doğrultusunda karşılaştırılması (Yüksek Lisans Tezi). Kocaeli Üniversitesi, Kocaeli.

Tolan, Y. (2011). Seviye Belirleme Sınavı (SBS) sorularının Fen ve Teknoloji dersi öğretim programına uygunluğu ve Bloom Taksonomisi'ne göre incelenmesi (Yüksek lisans tezi). Atatürk Üniversitesi, Erzurum.

Yıldırım, A., \& Şimşek, H. (2011). Sosyal bilimlerde nitel araştırma yöntemleri. Ankara: Seçkin.

Zoller, U. (1993). Are lecturing and learning compatible? Maybe for LOCS: Unlikely for HOCS. Journal of Chemical Education, 70 (3), 195-197.

Zoller, U., \& Tsaparlis, G. (1997). Higher and lower-order cognitive skills: The case of chemistry. Research in Science Education, 27, (1), 117130. 